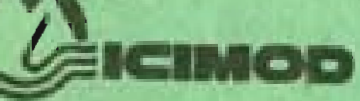

MOUNTAIN ENVTRONMENTAL MANAGEMENT DIVISION

Discussion Paper Series

\title{
MOUNTAIN ENVIRONMENTAL MANAGEMENT IN SWAT DISTRICT, PAKISTAN
}

Mohammad Aslam Khan, Mohammad Anwar, and Shabbir Baig,

MEM Series No. 5

1991

International Centre for Integrated Mountain Development: 
The opinions expressed in this publication are those of the author(s) and do not necessarily reflect the views of the International Centre for Integrated Mountain Development.

The designations employed and the presentation of the material in this publication do not imply the expression of any opinion whatsoever, on the part of the International Centre for Integrated Mountain Development, concerning the legal status of any country, territory, city, or area of its authorities: or concerning the delimitation of its frontiers and boundaries. 


\section{ENVIRONMENTAL MANAGEMENT IN SWAT DISTRICT, PAKISTAN}

MEM Series No. 5

Mohammad Aslam Khan is a Professor and the Chairman of the Department of Environmental Planning and Management, University of Peshawar. The late Mohammad Anwar was the Deputy Director of the National Institute of Public Administration. Shabbir Baig is the Deputy Director of the Soil Survey of Pakistan, Peshawar.

1991

International Centre for Integrated Mountain Development (ICIMOD)

Kathmandu, Nepal 


\section{PREFACE}

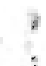

This Discussion Paper is an abridged version of the original study which was prepared for the International Symposium on Mountain Environmental Management, organised by ICIMOD in collaboration with UNESCO/MAB and held during April 1989. This study analyses the nature of environmental problems faced by a mountainous district in Pakistan and their causes and consequences within the given management framework. A critical evaluation of the current institutional set-up and management strategies has been undertaken to identify the gaps/shortcomings. Measures have also been suggested for the improvement of the environmental management framework in the area. The study formed part of a series of similar studies commissioned by ICIMOD in China, India, and Nepal. 


\section{CONTENTS}

\section{Page}

1. INTRODUCTION

Physical Environment 1

Relief and Drainage 1

Climate 1

Vegetation $\quad 2$

Human Habitat and Economy 2

Infrastructure $\quad 2$

2. ENVIRONMENTAL PROBLEMS 5

Resources $\quad 5$

$\begin{array}{ll}\text { Deforestation } & 6\end{array}$

$\begin{array}{ll}\text { Grazing Mismanagement } & 6\end{array}$

Erosion and Mass Movement $\quad 7$

Ecological Deterioration due to Agricultural Commercialisation 7

$\begin{array}{ll}\text { Species' Extinction } & 7\end{array}$

Human Settlements: Increasing Stress $\quad 7$

Industries as Resource Consumers and Generators of Waste 10

Tourism and Environment 11

Environmental Problems in Perspective 11

3. ENVIRONMENTAL MANAGEMENT : HISTORICAL PERSPECTIVE 12

Tribal or Pre-Wali Phase 12

Wali's Rule $\quad 12$

$\begin{array}{ll}\text { Contemporary Periods } & 14\end{array}$

4. ENVIRONMENTAL MANAGEMENT : PRESENT FRAMEWORK 16

$\begin{array}{ll}\text { Government Institutions } & 16\end{array}$

Planning and Management Institutions $\quad 16$

Sectoral Departments $\quad 17$

Regulatory' Institutions $\quad 17$ 
$\begin{array}{ll}\text { Community-based Institutions } & 17\end{array}$

$\begin{array}{ll}\text { NGOs/International Organisations } & 17\end{array}$

$\begin{array}{ll}\text { The Project Cycle and Environmental Assessment } & 17\end{array}$

$\begin{array}{ll}\text { Constraints/Obstacles to Environmental Management } & 18\end{array}$

Lack of Finances $\quad 19$

Fragmentation of Responsibilities $\quad 19$

Lack of Experts/Trained Staff 19

Deficient and Weak Instruments 19

Lack of Community Involvement and Public Awareness 19

The Kalam Integrated Forest Development Project (KIFDP) 20

5. ENVIRONMENTAL MANAGEMENT: PROPOSED FRAMEWORK

Appropriate Institutional/Organisational Structure 23

Regulatory Level $\quad 23$

Planning Level 24

Sectoral Level 24

Strengthening Institutional Capabilities 24

Environmental Monitoring/Information/Data Bank 25

District Environmental Plan 25

Research, Education/Public Awareness,

and Community Participation 26

Dissemination of State-of-the-Art

$\begin{array}{ll}\text { Knowledge in Environmental Management } & 27\end{array}$

$\begin{array}{ll}\text { Recommendations } & 27\end{array}$

$\begin{array}{ll}\text { REFERENCES } & 28\end{array}$

\section{LIST OF TABLES}

1. Swat District : Land Utilisation, $1987 \quad 6$

2. Swat District : Housing Units by Number of Rooms and Occupancy 8

3. Swat District: Housing Percentage

by Kitchen, Bathroom, and Latrine Facilities 9

4. Swat District: Air Pollutants Generated

by Firewood Use in an Average Household per Day 


\section{LIST OF FIGURES}

1. Map of Pakistan Showing the Study Area 3

2. Swat District: Altitudinal Zonation of Vegetation 4

3. Process of Commercialisation of Economic Activities and their Environmental Impacts in Swat $\quad 8$

4. Swat: Administrative Departments during State Period 13

5. Swat: Hierarchy of Administrative Areas during State Period 13

6. Kalam Integrated Forest Development Project
(KIFDP) Functional Structure

7. KIFDP: Institutional Structure for Management 22 